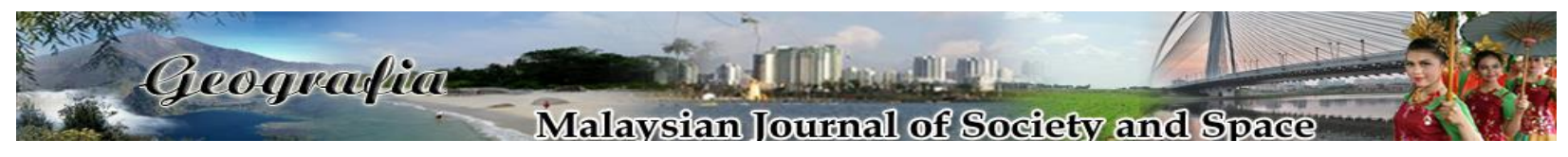

\title{
Assessment of erosion and hazard in the coastal areas of Selangor
}

\author{
Hamizah Ahmad ${ }^{1}$, Khairul Nizam Abdul Maulud ${ }^{1,2}$, Othman A. Karim ${ }^{1}$, Fazly Amri Mohd ${ }^{3}$ \\ ${ }^{1}$ Department of Civil Engineering, Faculty of Engineering and Built Environment, \\ Universiti Kebangsaan Malaysia \\ ${ }^{2}$ Earth Observation Centre, Institute of Climate Change, Universiti Kebangsaan Malaysia \\ ${ }^{3}$ Centre of Studies for Surveying Science \& Geomatics, Faculty of Architecture, Planning \& Surveying, \\ Universiti Teknologi MARA (Perlis)
}

Correspondence: Khairul Nizam Abdul Maulud (email: knam@ukm.edu.my)

Received: 28 April 2020; Accepted: 22 January 2021; Published: 27 February 2021

\begin{abstract}
Sea level rise is often associated with climate change and global warming. The change in shoreline is a continuous process that occurs through various processes such as erosion, sedimentation, sea level rise, wave behaviour and land use. Rapid technological advancement has made it possible to quickly identify the shoreline changes through a combination of Geographical Information Systems (GIS) application and Remote Sensing technology. The current study aims to identify the criteria or characteristics of the coastal areas and identify the risks for potential hazards in the coastal areas of Selangor. The data used in this study are the topographic maps produced in 1984 and SPOT 5 satellite images taken in 2013. The results of this study show that the estimated total area of erosion is 2,558 hectares and the total area of accretion is 2,583 hectares. The areas in Pasangan, Tanjong Karang, Api-Api, Bagan Nakhoda Omar, Jeram, Pasir Panjang, Hujong Permatang, Kuala Selangor and Panchang Bedena are categorized as critical erosion areas. Risk assessment analysis was done to identify the risk levels of coastal erosion hazards. Results indicate that the risk level for human, social and economic components is low while the level for infrastructure components ranges between low and moderate. However, the risk for coastal erosion hazards for the environment is high. The results of this study provide the critical information required by government agencies to formulate policies and implement an Integrated Coastal Management Plan in the effort to effectively deal with climate change and sea level rise phenomenon.
\end{abstract}

Keywords: erosion, geospatial, sea level rise, shoreline change, risk identification

\section{Introduction}

Coastal erosion is one of the more serious problems faced by all countries, where erosion has endangered human activities in the coastal areas. Coastline retreats may have a very serious social, 
environmental and economic impacts depending on the eroded area (Bagheri et al., 2019). Malaysia is surrounded by the sea and is endowed with rich biodiversity and natural resources, including wildlife and marine life. Malaysia has a land area of $329,758 \mathrm{~km}^{2}$ and a coastal zone that transverse 4,809 kilometres. The coastline of Peninsular Malaysia is approximately 2,902 km long, and more than $90 \%$ of the coastal area is made up of easily erodible alluvium. From November 1984 to January 1986, the Malaysian government has conducted a study on national coastal erosion and found that about $29 \%$ or $1,380 \mathrm{~km}$ of the country's coastline is under the threat of coastal erosion (Economic Planning Unit, 1985). Muslim (2004) contended that 2,327 km of the coastline is exposed to erosion. The shoreline of Peninsular Malaysia can be categorized either as muddy or sandy beaches. Most of the sandy beaches are located in the east coast of Peninsular Malaysia, which extend from the Kelantan shoreline in the north all the way south to the east Johor shoreline, while the muddy beaches are mostly located in the west coast of the peninsular (Hashim et al., 2017). The shoreline, especially in the east and south of Malaysia, is vulnerable to natural processes, including wind, wave, tidal current, and sea level rise.

In Malaysia, erosion is caused by the change in sea level human activities and dynamic process (Zhang \& Hou, 2020). The temperature and rainfall in Malaysia are anticipated to rise between +0.6 and $3.4{ }^{\circ} \mathrm{C}$ and -1 to $32 \%$ in 60 years, respectively, whereas the sea level is projected to rise approximately 13-94 cm in 100 years (Initial National Communication, 2000). These could have an adverse impact on water resources, coastal zones activities such as tourism and fisheries, flood supply, and public health, all of which may require national and international responses to deal with climate change (Hassan \& Rahmat, 2016; Razak et al., 2018; Salleh \& Nadzir, 2019). In addition, these problems aggravate the potential susceptibility, risk, and hazard to the development of the coastal township. According to the study conducted by the National Hydraulic Research Institute of Malaysia (NAHRIM) (2010), the average sea level rise in Malaysia from 2000 to 2050 is projected to be approximately $0.25 \mathrm{~m}$, which is equivalent to $5 \mathrm{~mm}$ per year. In addition, Ong (2000) pointed out that there is geological evidence that, for the past 5,000 years, the sea level in Malaysia has fallen approximately $1 \mathrm{~mm}$ per year and that the global tidal level has dropped $2.4 \pm$ $0.9 \mathrm{~mm}$ per year.

Furthermore, the National Coastal Erosion Study (NCES) carried out by the government of Malaysian in 2016 has identified the Selangor coastal areas as being vulnerable to hazards that could result in a catastrophy. All the studies mentioned above are an indication that the Malaysian coastal zone is vulnerable to sea level rise. According to Stanley \& Lewis (2009), rising sea level allows for seawater to penetrate further inland and increase the potential risk of shoreline erosion and degradation. Among the possible impact of sea level rise are the destruction of assets, disruptions to economic activities, loss of human lives, the effect on people's mental health, and loss of plants, animals, and ecosystem; the severity of these impacts are dependent on the extremes, exposure and vulnerability. Therefore, the present study was conducted to detect the criteria or characteristics of the Selangor coastal area from Sabak Bernam to Kuala Langat. This study also aimed to develop a spatial model for identifying the area of erosion and accretion. In the light of this, the present this study seeked to identify the potential hazards as well as assess the risks in the coastal areas of Selangor. 


\section{Literature review}

The coast is the area that separations the coastal land from the sea (Mohd Azharn et al., 2018) 2018). Hashim \& Noor, (2013) and Mohd et al., (2019) stated that most coastal areas on the east coast of Peninsular Malaysia are going through a critical erosion process. However, an opposite phenomenon is being observed in most of the areas on the west coast of Peninsular Malaysia. Yanalagaran \& Ramli (2018) discovered that the beaches on the east coast of Peninsular Malaysia are directly exposed to the weather phenomenon during the northeast monsoon, where large aggressive waves are capable of eroding the coastal zone (National Coastal Erosion Study, 2016). On the contrary, in the west of Peninsular Malaysia the wind and wave action are moderate and less aggressive and thus serve as corrosion agents rather than an agent of deposition (Ghazali, 2006; Hashim \& Noor, 2013; Jaharudin et al., 2019; Mohammad et al., 2007; Stanley \& Lewis, 2009). The beaches in Selangor are not spared from both the natural process of coastal erosion and deposition (Ehsan et al., 2019; Razak et al., 2018; Selamat et al., 2017). As one of the most developed states in Malaysia, Selangor goes through a very rapid development process. The change in land use occurs rapidly, and this has the effect of removing the eroded sediments into the river system that flows straight into the Straits of Malacca.

Most shoreline changes are regarded as a major dynamic change in coastal areas (Ehsan et al., 2019; Jaharudin et al., 2019; Mohd Azharn et al., 2018; Mohd et al., 2019; Rameli \& Jaafar, 2018; Selamat et al., 2017; Stanley \& Lewis, 2009), where the two main causes of shoreline changes are natural activities in the area and human activities. Mohd Azharn et. al. (2018) investigated the shoreline changes that are caused by natural activities through the combined actions of waves, currents, tides and river flow, which often lead to a conflict in the process of coastal erosion. The changes related to human activities are the result of increasing population and unplanned development in coastal areas. According to Mohd Azharn et. al. (2018), the major issues for coastal zones to determine the boundary of a region is the characteristic of the shoreline itself.

Furthermore, coastal accretion and erosion are unavoidable processes as coastal sediments are constantly being moved due to the effects of tides, currents, winds, and waves. Daily activities such as harbour construction and sand dredging disrupt the continuity of sediment transport and thus accelerate coastline erosion (Yanalagaran \& Ramli, 2018). In addition, sea level rise, climate change, and storm surges add another layer of complication to the erosion of coastlines. Rameli \& Jaafar (2018) posited that changes in coastal areas, or more precisely the changes in the shoreline, are also strongly influenced by the effects of sea level rise as a result of global climate change.

According to Asmawi \& Ibrahim (2013), the loss of coastal island has an adverse economic and ecological impact. In Peninsular Malaysia, the intrusion of seawater has caused damage to large areas of agricultural land and properties; public facilities and coastal roads have been destroyed and caused transportation delay. The intrusion of seawater has also caused damage to beaches and this have had adverse impact on the tourism industry (Ehsan et al., 2019; Ghazali, 2006; Hassan \& Rahmat, 2016; Mohd et al., 2019; Rameli \& Jaafar, 2018; Razak et al., 2018; Selamat et al., 2017; Stanley \& Lewis, 2009, 2009).

In the past, field measurements were made to gather coastal data positions which are the used to determine shoreline changes (Mohd Azharn et al., 2018). In the present day, Geospatial technology, which includes Geographical Information System (GIS) and satellite Remote Sensing, is used to store, extract, analyze and map shoreline changes (Selamat et al., 2017). Din Hashmi \& Ahmad (2018) pointed out that several studies have used Geographic Information system-based approaches to obtain a more in-depth information about the short term and long-term changes in 
the coastal areas and marine environment. GIS is not only useful for testing the model but it is able to provide visual information of coastline changes.

GIS integrates the location of spatial information with information about its attributes. GIS and remote sensing technology are able to calculate the historical rate of change. Information such as aerial photographs, topographic, bathymetric surveys, beach profiles, and historical maps can be used to qualitatively and quantitatively assessment the spatial and temporal changes in coastal areas (Mohd Azharn et al., 2018; Selamat et al., 2017). The latest GIS and remote sensing technologies are capable of extracting and detecting shoreline changes from satellite images (Asmawi \& Ibrahim, 2013; Camara et al., 2019; Din Hashmi \& Ahmad, 2018; Hassan \& Rahmat, 2016; Mohammad et al., 2007; Mohd Azharn et al., 2018; Nassar et al., 2019; Pantanahiran, 2019; Selamat et al., 2017). According to Pantanahiran (2019), in order to calculate erosion and deposition in coastal areas, GIS requires inputs such as aerial photographs and satellite images.

Geospatial technology has been recognized as an effective technique in the process of monitoring, analyzing, and predicting shoreline changes. This has been proven by many researchers who conduct their studies using GIS and remote sensing approaches to determine shoreline changes and were able to produce valuable information and results.

\section{Study area and methodology}

This study was conducted along the shoreline of Selangor on the west coast of Peninsular Malaysia, extending from Sabak Bernam to Kuala Langat at $100^{\circ} 51^{\prime} 31.43^{\prime}$ E to $101^{\circ} 36^{\prime} 7.52^{\prime \prime}$ E and $3^{\circ}$ $47^{\prime} 0.59^{\prime \prime} \mathrm{N}$ to $2^{\circ} 39^{\prime} 14.17^{\prime \prime} \mathrm{N}$, as shown in Figure 1. The coastal areas of Selangor are generally muddy. According to Hashim \& Noor (2013), the west coast of Peninsular Malaysia faces the Straits of Malacca, which is a narrow stretch of water between Malaysia and the island of Sumatra. The strait is sheltered by the Island of Sumatra and thus has a mild wave condition. Most parts of the west coast of Peninsular Malaysia are mudflats that are rich with diverse species of mangrove that promote the growth of marine life and play an important role in dissipating wave energy. The mangrove habitats along the coastline, which help to dissipate wave energy, has been destroyed and this has resulted in a rapid coastal erosion (Ehsan et al., 2019; Ghazali, 2006; Hashim et al., 2010; Lee et al., 2014; Stanley \& Lewis, 2009). The study covers $276 \mathrm{~km}$ of the Selangor coastline and is divided into smaller units known as the Management Unit (MU). The MU is defined as a length of shoreline with coherent characteristics in terms of administration, land use and natural coastal processes. This study is divided into three MUs, which are MU1, MU2 and MU3, based on the National Coastline Zone Physical Plan (JPBD, 2012) summarised in Table 1. 


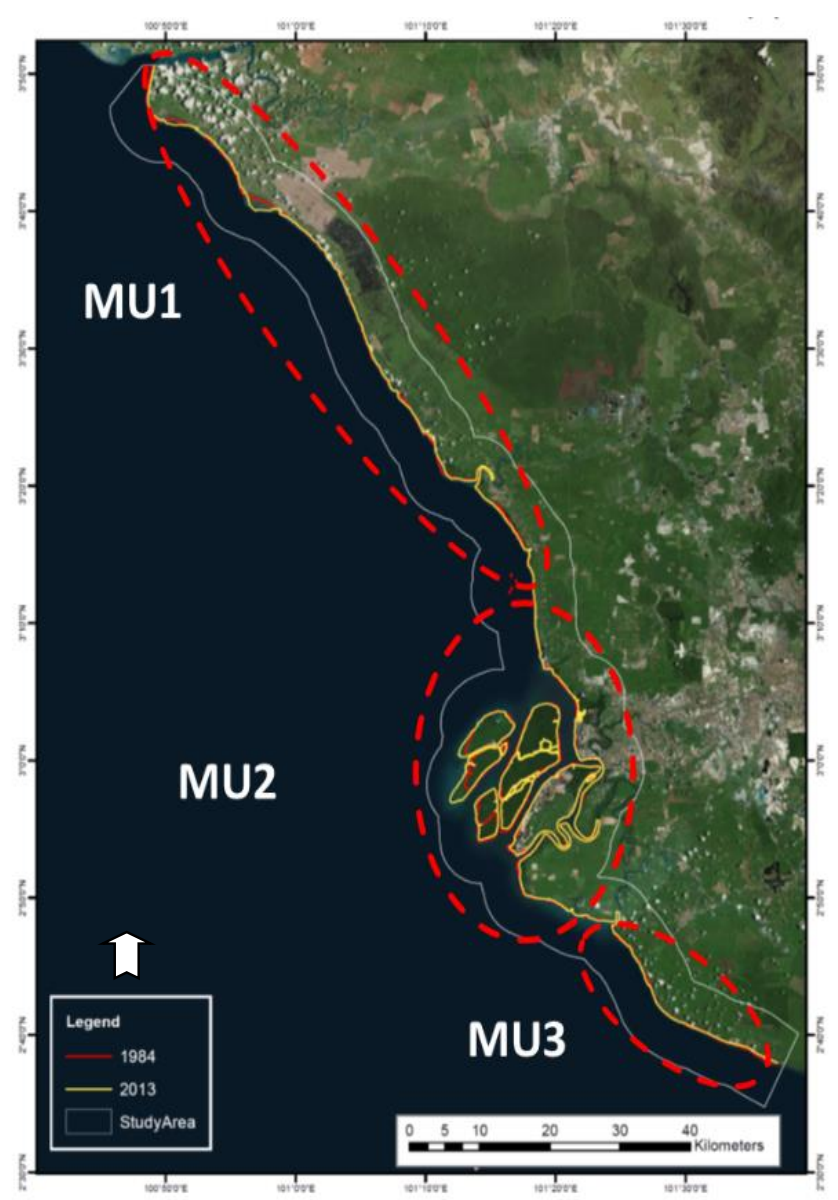

Figure 1. Study area

Table 1. MUs for the Selangor Coastal Area from Sabak Bernam to Kuala Langat

\begin{tabular}{clll}
\hline $\begin{array}{c}\text { Management } \\
\text { Unit }\end{array}$ & \multicolumn{1}{c}{ Shoreline area } & District & \multicolumn{1}{c}{ Sub-district } \\
\hline MU1 & $\begin{array}{l}\text { Sungai Bernam to Northern } \\
\text { boundary Sub-district of } \\
\text { Kapar }\end{array}$ & $\begin{array}{l}\text { Sabak } \\
\text { Bernam } \\
\text { Kuala } \\
\text { Selangor }\end{array}$ & $\begin{array}{l}\text { Jeram, Bagan Nakhoda Omar, Kuala Selangor, } \\
\text { Panchang Bedena, Pasir Panjang, Tanjong } \\
\text { Karang, Pasangan, Api-Api \&. Hujong } \\
\text { Permatang, }\end{array}$ \\
& $\begin{array}{l}\text { Korthern boundary Sub- } \\
\text { district of Kapar to Southern } \\
\text { border Sub-district of }\end{array}$ & $\begin{array}{l}\text { Kuala } \\
\text { Selangor }\end{array}$ & $\begin{array}{l}\text { Kelanang, Klang, Jugra, Teluk Panglima } \\
\text { Karang and Kapar }\end{array}$ \\
& $\begin{array}{l}\text { Kelanang } \\
\text { Southern boundary Sub- } \\
\text { district of Kelanang to } \\
\text { MU3 }\end{array}$ & Kuala & Morib, Batu, Jugra, Teluk Panglima Garang, \\
& Langat & Bandar \\
& Kuala Langat & & \\
\hline
\end{tabular}

Geospatial technology is a tool that allows the end users to generate, monitor, analyse and manipulate data in accordance with their needs. In this study, the use of geospatial technology has allowed researchers to identify shoreline changes. The assessment was based on the observations made during site visits and the data collected along the coastline from Sabak Bernam to Kuala Langat. The shoreline 
topographic map for 1984 provided by the Department of Survey and Mapping Malaysia (JUPEM) and the shoreline data extracted from the Spot 5 images taken in 2013 were used in this analysis. All data were analysed using the ArcGIS 10.2 software and the identified shoreline changes were displayed in the form of maps. Figure 2 shows the research framework adopted in this study. The illustration in Figure 3 is the spatial model generated in ArcGIS to identify the eroding and accreting shoreline through the overlay process of the baseline map and satellite images. The observations made during site visits were also used to determine the potential risk in the Selangor coastal area.

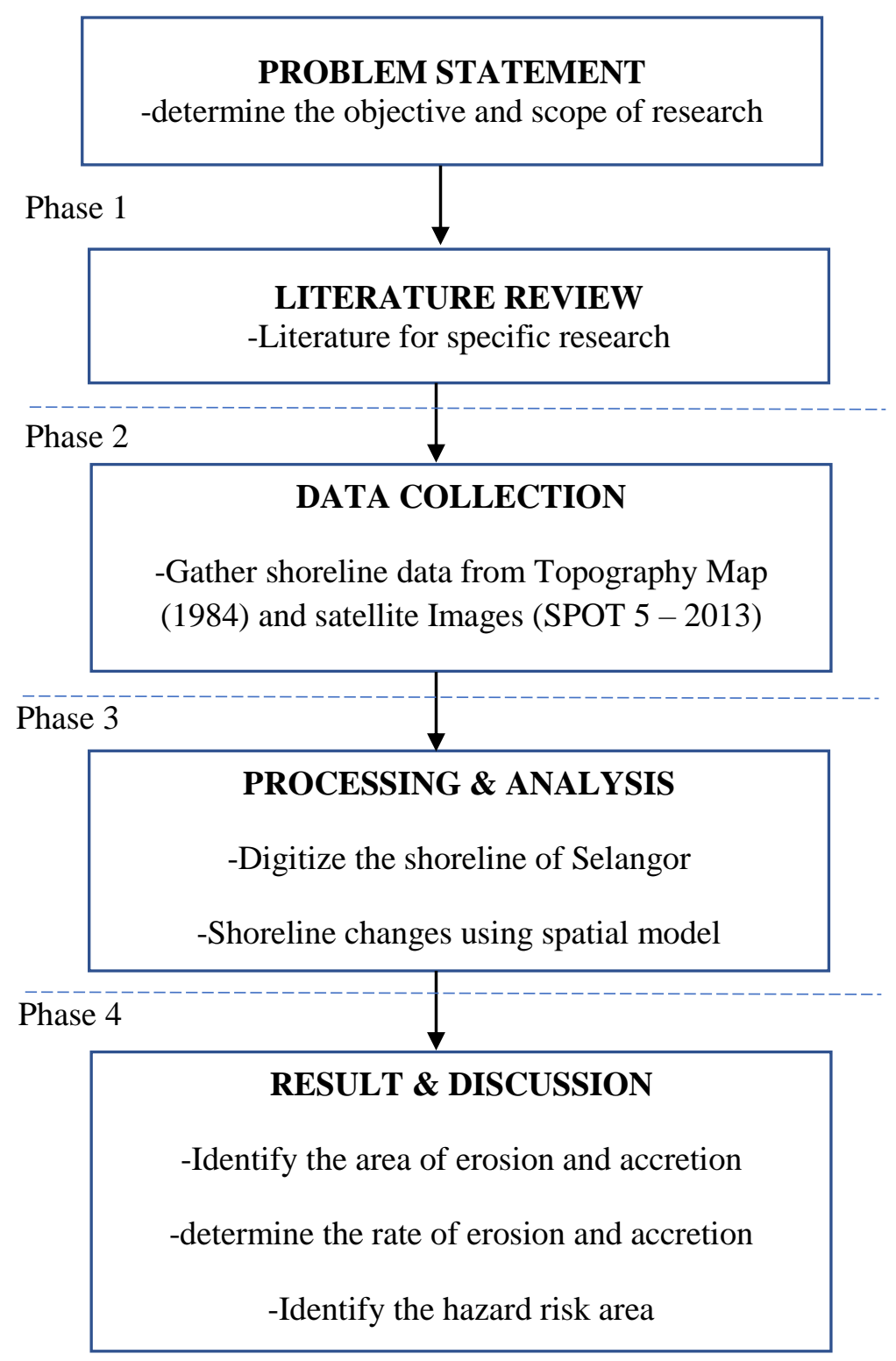

Figure 2. Flow chart of the research framework 


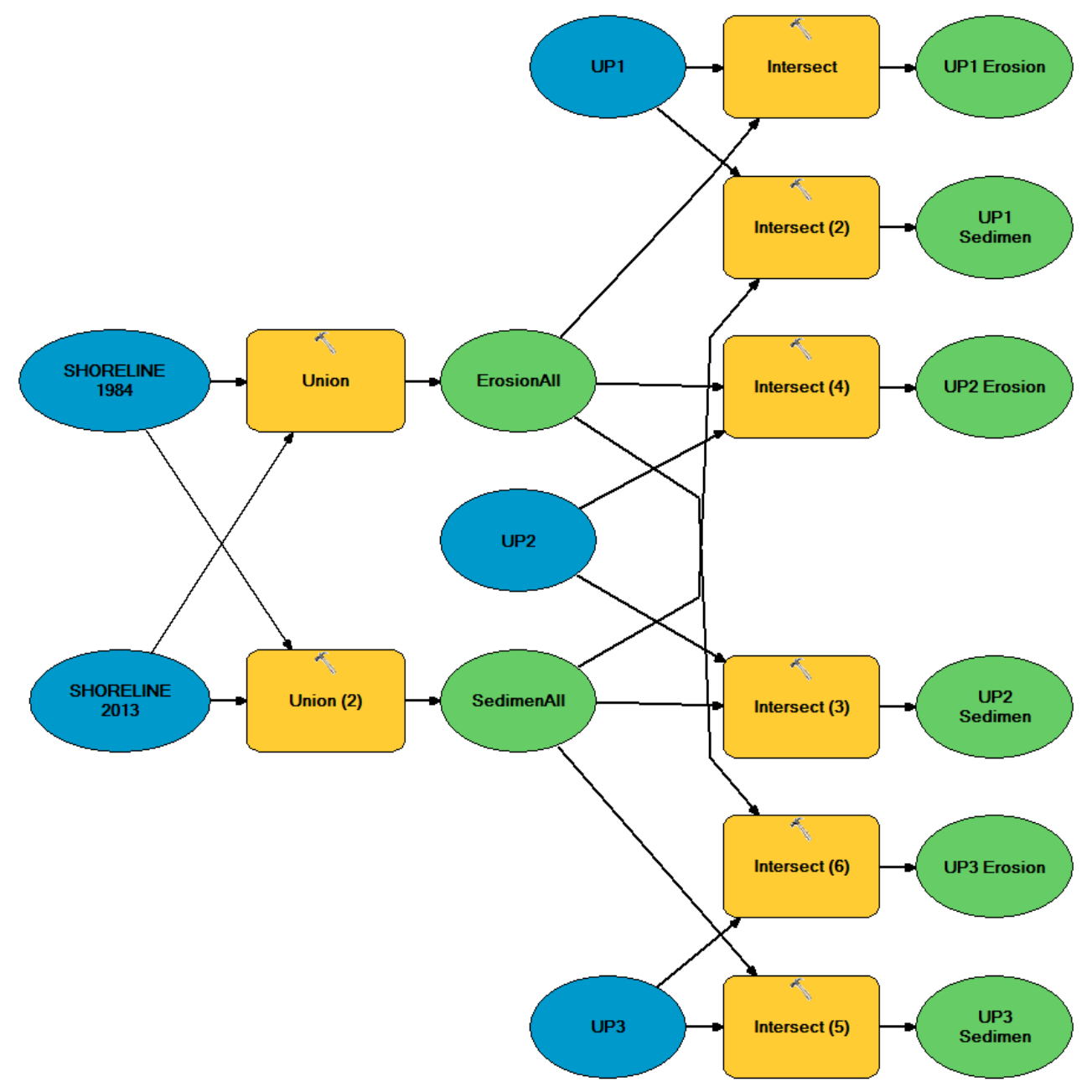

Figure 3. Shoreline Changes Spatial Model

\section{Result and discussion}

\section{Criteria and characteristics of the coastal area of Selangor}

Coastal areas can be categorized into three types, namely sandy, muddy and rocky beaches. The beaches in Selangor are muddy (Hashim \& Noor, 2013; Mohd Azharn et al., 2018; Rameli \& Jaafar, 2018; Selamat et al., 2017). The muddy beach has a very smooth substrate with a diameter of less than $0.002 \mathrm{~mm}$ (Nybakken, 1988). This type of beach is located at the mouth of rivers that carry sediments into the sea. The wave at a muddy beach is calm and is not able to carry sediment into the waters. Muddy beaches are conducive for coastal plants such as mangroves which serve as a breakwater that helps to reduce coastal erosion.

In this study, all MUs have extensive areas of muddy beach, such as Pantai Bagan Nakhoda Omar as shown in Figure 4 (a), the estuary of Sungai Haji Dorani, Pulau Indah, Pantai Morib and Pantai Batu Laut. The west coast of Peninsular Malaysia is conquered by mud flats and made up 
$72 \%$ of the west coast. These areas are typically lined with extensive mangrove belts such as those in Perak, Selangor and Johor (Ghazali, 2006). Hashim \& Noor (2013) pointed out that the mangrove bands along the coastline, which dissipate wave energy, has been demolished and this has resulted in rapid coastal erosion. These areas, for instance Pulau Indah, have been experiencing diminishing mangrove swamps which serve as natural protection against erosion (Figure 4 (b)).

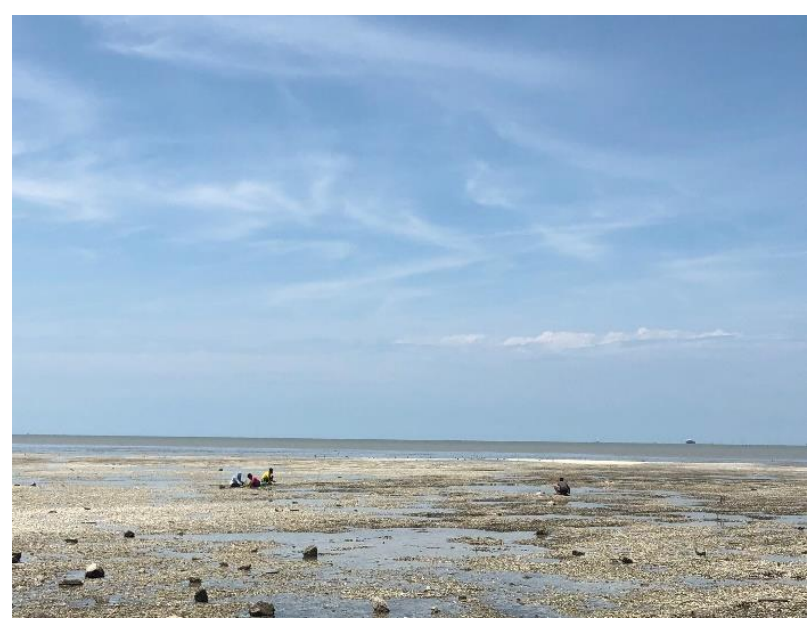

(a)

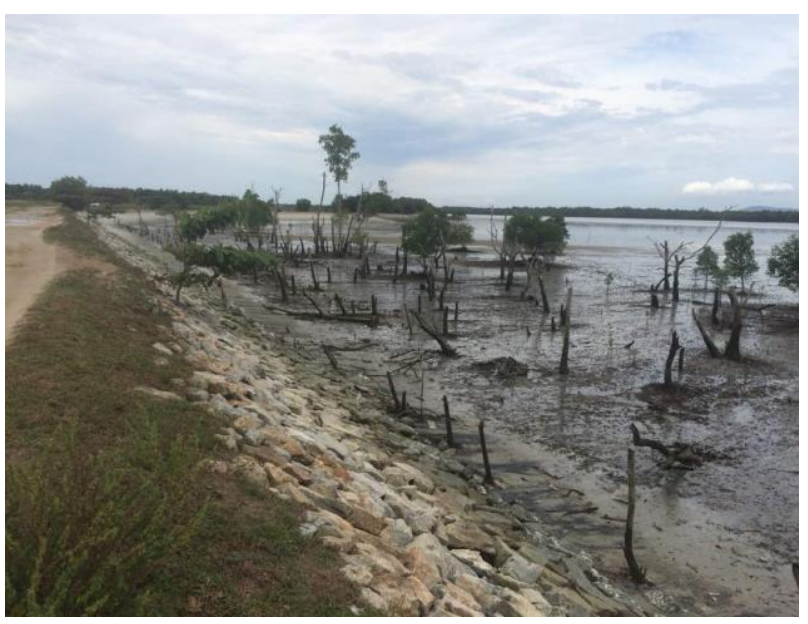

(b)

Figure 4. Characteristics of the beaches in the Selangor coastal area

\section{Analysis of shoreline changes}

The two main factors causing shoreline changes are erosion and accretion. Coastal erosion is the process of degrading, carving and transferring of materials in coastal areas by erosion agents such as wave, tsunami and tides. Accretion occurs when the beach experiences material addition due to the deposition of material from the river. According to Granados and Peterson (1999), uncontrolled coastal erosion has an indirect effect human life, environment and ecosystem. Figure 5 shows the erosion and accretion that have caused shoreline changes along with the coastal areas of Selangor for the period between 1984 to 2013. The mapping of the shoreline was done by the Department of Survey and Mapping Malaysia (JUPEM). The shoreline is a sensitive area and will change continuously if preventive measures are not implemented. The topographic maps and satellite images show the changes that occur between 1984 and 2013. 


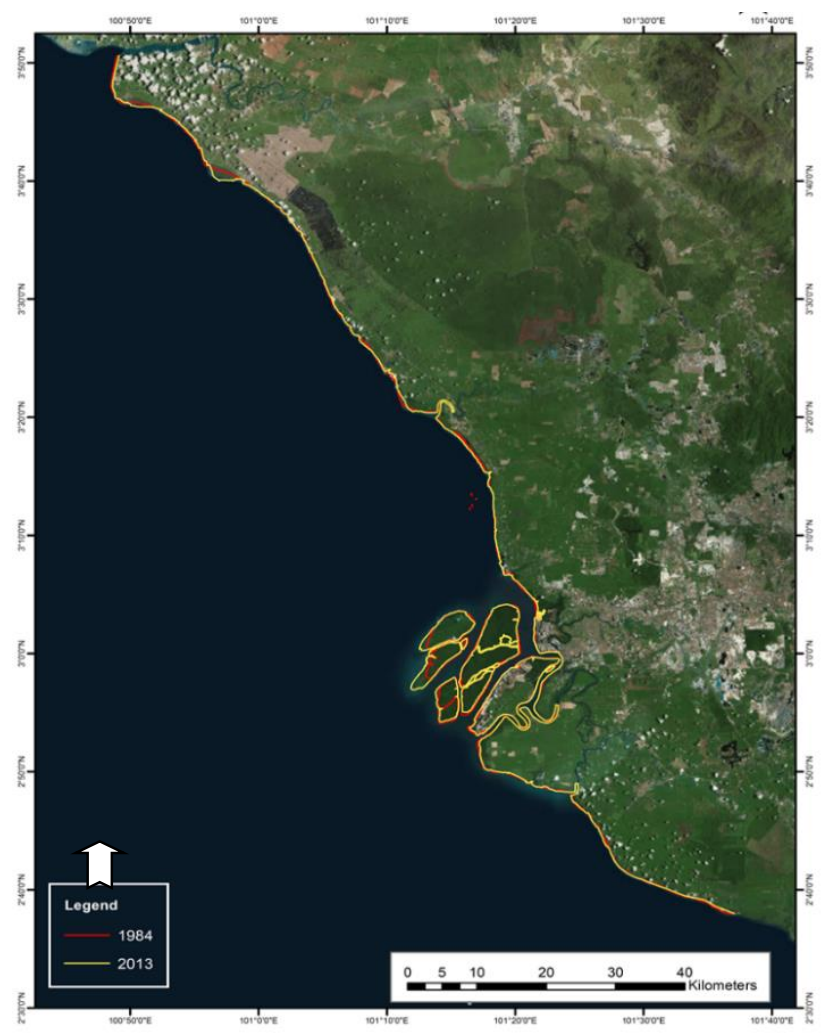

Figure 5. Shoreline change along the coastal area of Selangor between 1984 and 2013

After identifying the shoreline changes along with the coastal areas of Selangor for the period between 1984 and 2013, the area of erosion and accretion for the 30-year period can be determined. The maps in Figure 6, Figure 7 and Figure 8 show the areas of accretion and erosion for MU1, MU2 and MU3, respectively.
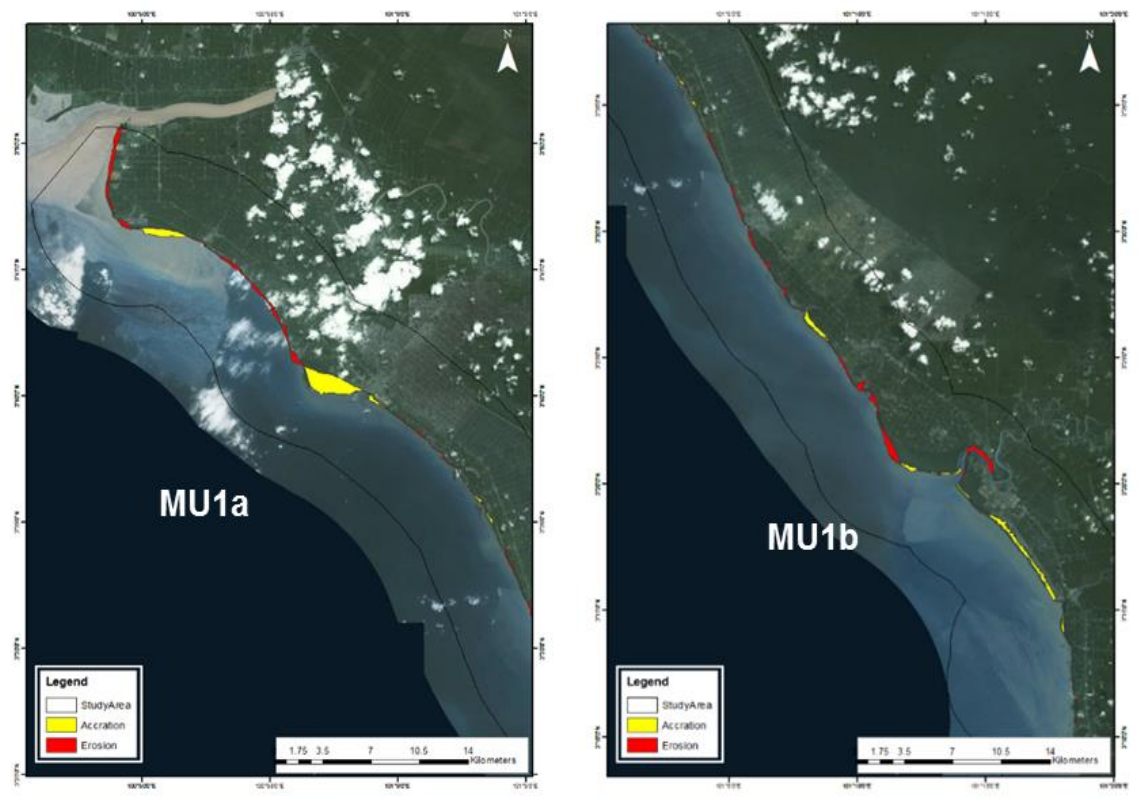

Figure 6. Map of erosion and accretion in MU1 


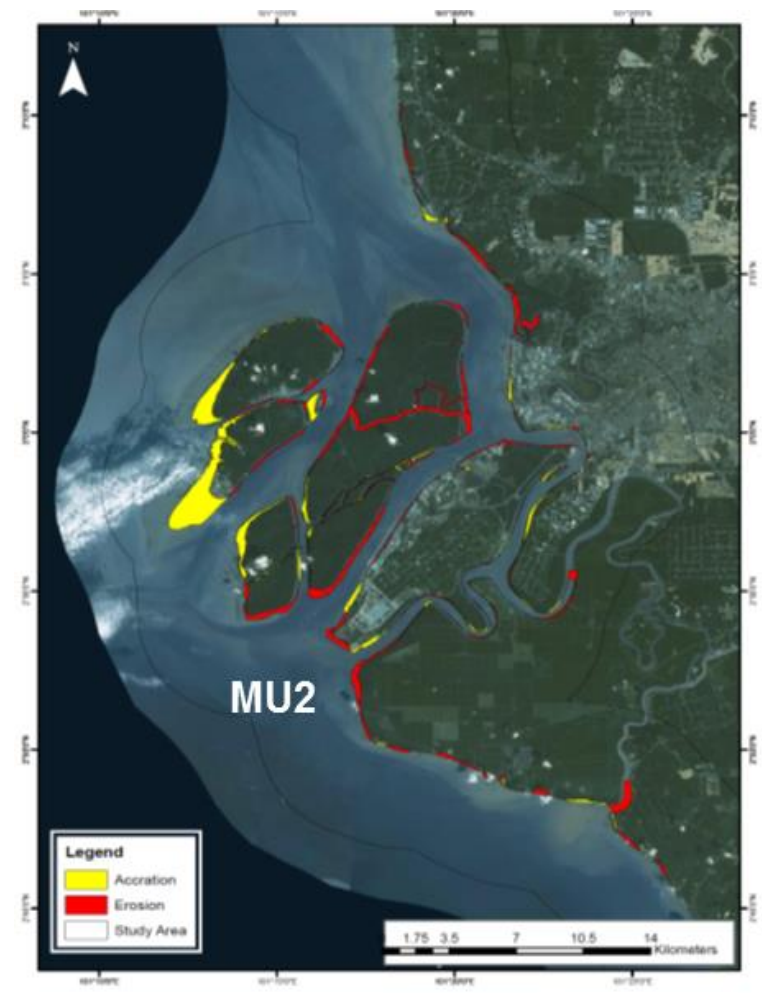

Figure 7. Map of erosion and acccretion in MU2

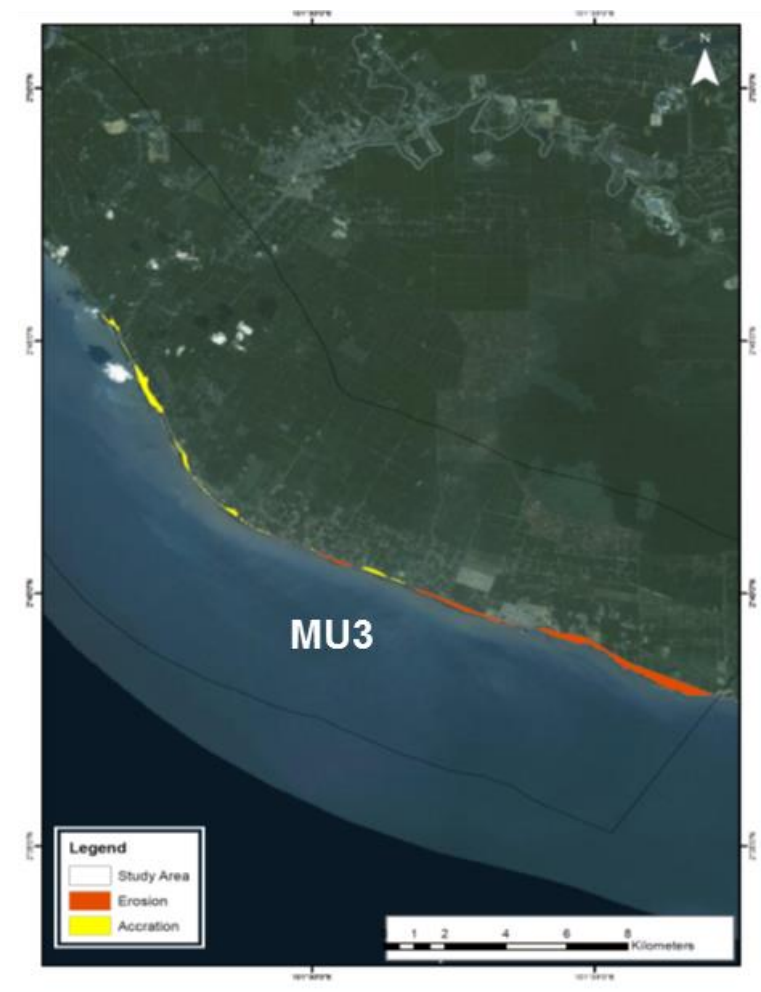

Figure 8. Map of erosion and accretion in MU3

The total area of erosion in the Selangor coastal area is 2,558 and the total area of accretion is 2,583 hectares. The area with the highest level of accretion is MU2 (Bernam River to Kapar Kapar District) followed by MU1 (Bernam River to Kapar District) and MU3 (Sungai Terap to Kuala Sungai Selangor). The areas with the highest level of erosion and accretion is MU2 with a total area of 1,549 hectares and 1,543 hectares, respectively. Table 2 presents a summary of the area of erosion and accretion in the Selangor coastal area for the period between 1984 and 2013 based on management units; the results are presented graphically in Figure 9.

Table 2. Area of erosion and accretion for the Coastal Area of Selangor between 1984 and 2013

\begin{tabular}{|c|c|c|c|}
\hline Management Unit & Shoreline area & $\begin{array}{c}\text { Erosion } \\
\text { (Ha) }\end{array}$ & $\begin{array}{l}\text { Accretion } \\
\text { (Ha) }\end{array}$ \\
\hline MU1 & Sungai Bernam to Northern border Sub-district of Kapar & 813 & 960 \\
\hline MU2 & $\begin{array}{l}\text { Northern border Sub-district of Kapar to Southern border } \\
\text { Sub-district of Kelanang }\end{array}$ & 1,549 & 1,523 \\
\hline MU3 & $\begin{array}{l}\text { Southern border Sub-district of Kelanang to Southern } \\
\text { border district of Kuala Langat }\end{array}$ & 196 & 100 \\
\hline TOTAL & & 2,558 & 2,583 \\
\hline
\end{tabular}




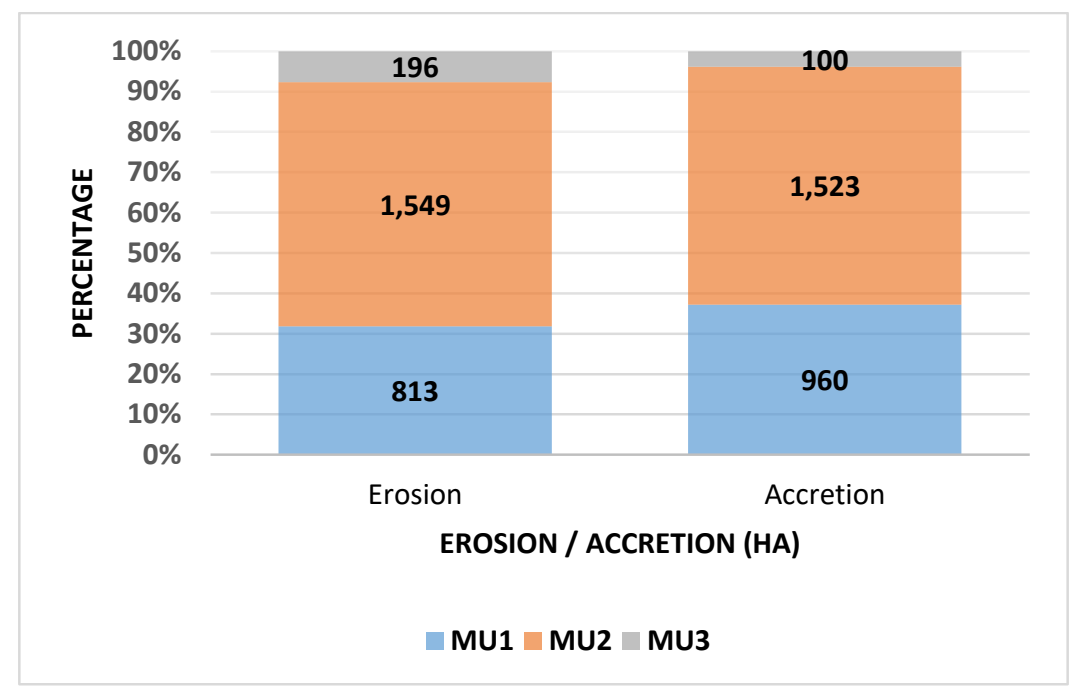

Figure 9. Erosion and accretion at the Selangor coastal area

Table 3 presents the annual rate of accretion and erosion at the Selangor coastal area. The rate of change varies with the area. The rate of erosion ranges from 4.81 to $6.39 \mathrm{~m} / \mathrm{yr}$, while the rate of accretion ranges from 4.36 to $13.88 \mathrm{~m} / \mathrm{yr}$. The highest rate of accretion and erosion is in MU1.

Table 3. Rate of erosion and accretion for the Selangor coastal area from 1984 to 2013

\begin{tabular}{lccll}
\hline Management Unit & Erosion & $\begin{array}{c}\text { Accretion } \\
(\mathbf{m})\end{array}$ & $(\mathbf{m})$ & \multicolumn{2}{c}{ Annual rate $(\mathbf{m} / \mathbf{y r})$} \\
\cline { 4 - 5 } & 191.70 & 416.30 & 6.39 & 13.88 \\
\hline MU1 & 189.00 & 130.67 & 6.30 & 4.36 \\
MU2 & 144.25 & 155.75 & 4.81 & 5.19 \\
\hline
\end{tabular}

Risk assessment analysis

Hazard identification, risk assessment and risk control are of critical significance in the management planning and execution of an operation by organisations. Risks can be expressed in various ways to provide analytical results to be used in the determination of risk control. Based on Guidelines for Hazard Identification, Risk Assessment and Risk Control (HIRARC) by DOSH (2008), the risk is defined as a combination of factors between the occurrence of an undesirable event within a certain period or condition with potential severity factors which may cause injury or adverse impact on health, property, environment or any combination of these factors. Two critical elements in risk assessment are likelihood and severity.

Risk assessment analysis is based on the risk matrix method (Figure 10) which determines the risk in qualitative, quantitative or semi-quantitative data. The definition of the score for probability and severity in the risk matrix is adapted from Thomsen et al., 2012. In this study, the potential hazard risks in the Selangor coastal area is based on the observations of current conditions and the history of previous disasters. Site visits to the study area were made on 4 and 5 August 2018 based on the management units. Risk analysis was carried out and classified based on the risk matrix. 


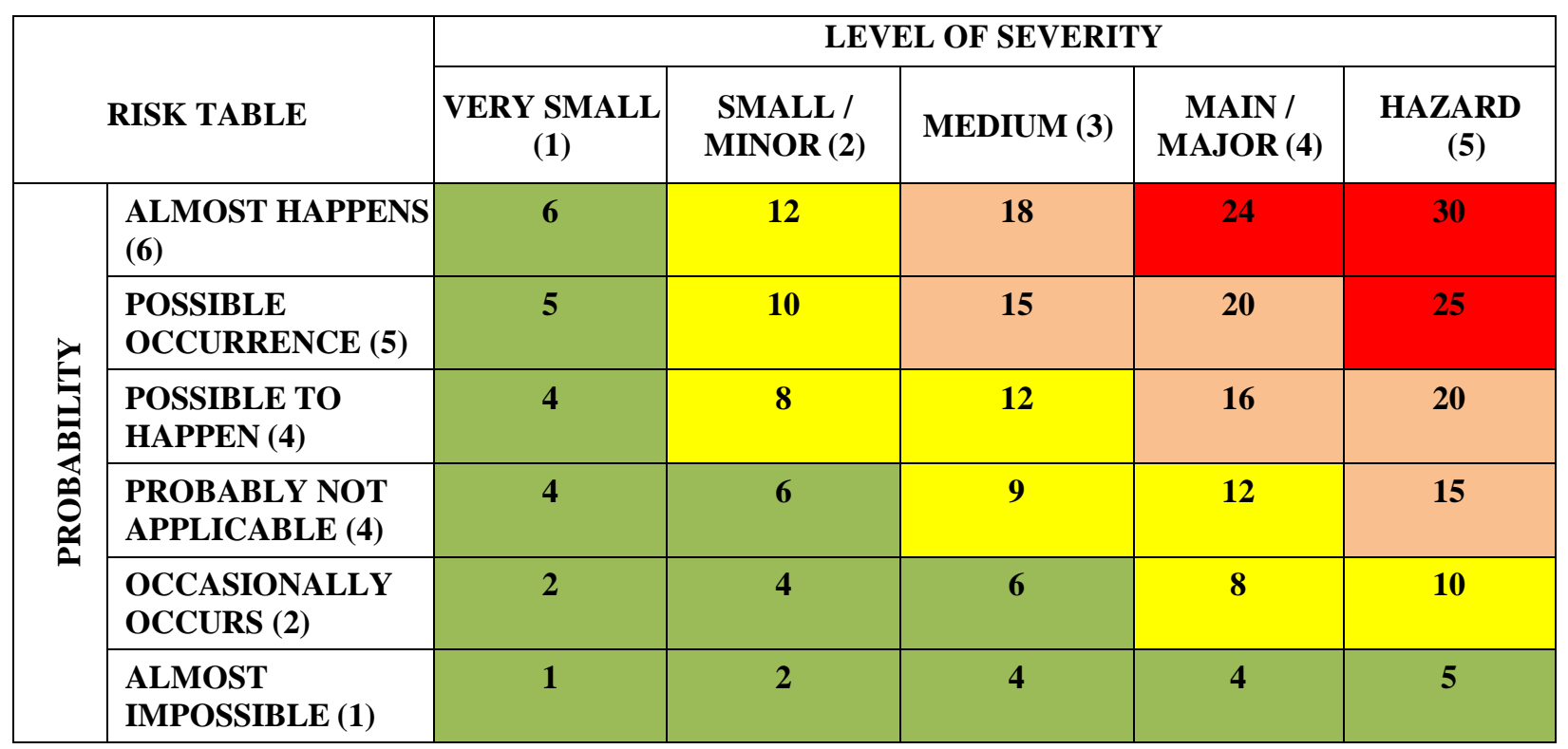

\begin{tabular}{|l|l|l|l|l|l|l|l|}
\hline$<8$ & LOW & $8-12$ & MEDIUM & $15-20$ & HIGH & $>24$ & VERY HIGH \\
\hline
\end{tabular}

Source Adapted from Thomsen et. al. (2012)

Figure 10. Risk assessment based on the risk matrix

\section{a. Coastal area of MU1}

The shoreline in MU1 showed the highest erosion rate compared to MU2 and MU3. The risk of erosion along the MU1 shoreline was assessed based on the frequency of erosion and severity of the impact of coastal erosion. Based on the observation made during the site visits, the erosion in MU1 occurred continuously. One of the study areas in MU1, Sungai Haji Dorani, is located in the district of Sabak Bernam where agriculture and fisheries are the principal economic activities. The beach in this area consists of soft clay and mud deposited by nearby rivers. The wave climate, according to Unit Perancang Ekonomi (1985), is reasonably mild with a wave height of less than $1.50 \mathrm{~m}$ in normal condition and 2 to $3 \mathrm{~m}$ high during a severe storm. Hashim \& Noor (2013) pointed out that the development along the coastline has led to deforestation of the mangrove forests, which in consequence has caused erosion. Government agencies have been implementing initiatives to mitigate erosion problems. Therefore, the score for erosion frequency for this are is almost certain to happen. The severe impact of coastal erosion occurred extensively along most of the MU1 shoreline. The impacts of erosion vary depending on the risk of respondents/recipients. The score for the magnitude of the severity of the various risk recipients is based on the definition adapted from the Thomsen et al., 2012. Table 4 summarises the risk assessment analysis for the erosion hazard in MU1 based on the risk matrix. The current condition in MU1 is shown in Figure 11. 
Table 4. Risk analysis assessment on coastal erosion in MU1

\begin{tabular}{cllll}
\hline Hazard & $\begin{array}{c}\text { Risk } \\
\text { Respondent }\end{array}$ & \multicolumn{1}{c}{ Frequency } & Severity & Risk \\
\hline Human & $\begin{array}{l}\text { Almost certain to } \\
\text { happen } \\
\text { Almost certain to } \\
\text { happen }\end{array}$ & Very low & Low \\
Coastal Erosion & Economy & $\begin{array}{l}\text { Almost certain to } \\
\text { happen } \\
\text { Almost certain to } \\
\text { happen } \\
\text { Almost certain to }\end{array}$ & Low \\
& Environment low & Low \\
Infrastructuren & Very low & Low \\
\hline
\end{tabular}

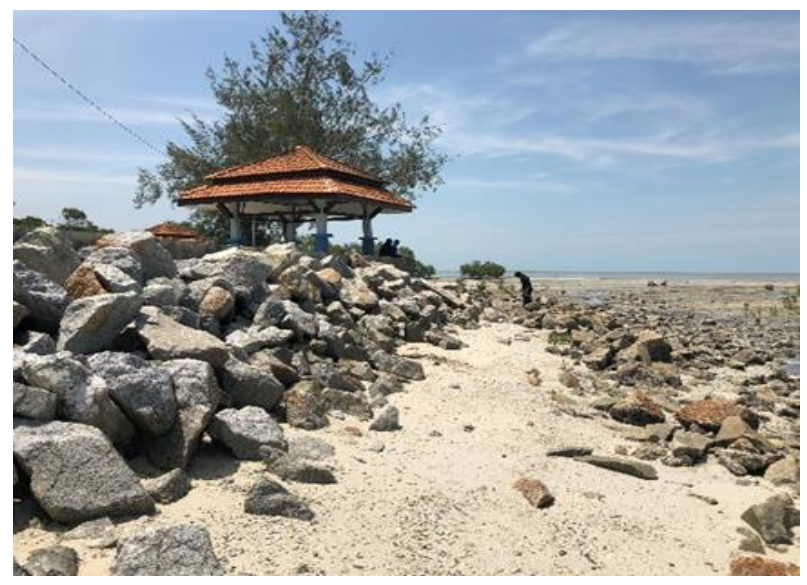

(a)

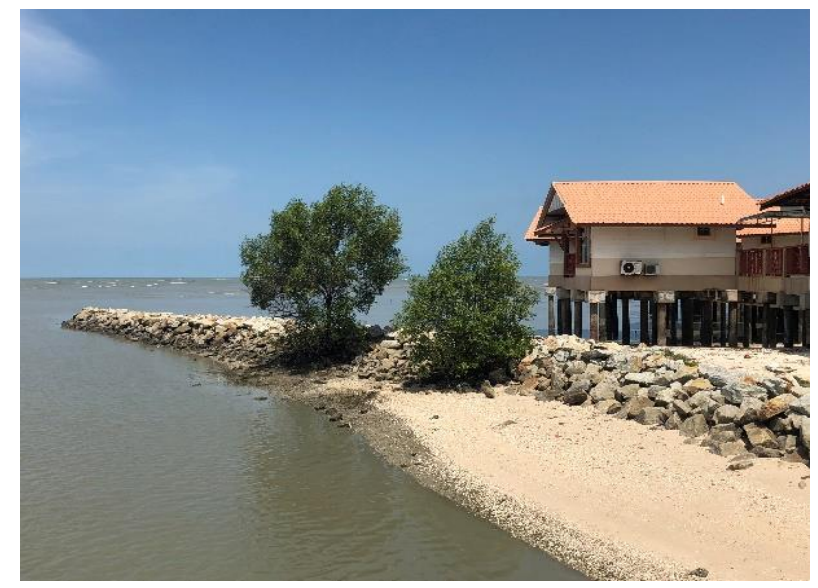

(b)

Figure 11. Current condition showing the construction of wave breakers at (a) Pantai Bagan Nakhoda Omar; and (b) Dorani Bayu Resort

\section{b. Coastal area of MU2}

The shoreline of MU2 experienced the second highest erosion rate compared to MU1 and MU3. The risk of erosion along the MU2 shoreline was assessed based on the frequency of erosion and severity of the impact of coastal erosion. Based on the observation made during the site visits, MU2 experienced continuous erosion. Human factors such as the movement of large ships in the Straits of Malacca are believed to play an important role in promoting the process of erosion in this area, especially in the northern coast of Carey Island. This section is located close to Port Klang which has a high volume of large ship traffic. Large vessels are capable of producing energy waves that act as an agent of erosion when they arrive at the beach. Based on the initial findings made by (Rameli \& Jaafar, 2018), it is clear that the coast of Carey Island-Morib is exposed to the greater process of erosion compared to deposition. Generally, both processes are strongly influenced by the action of the dynamic agents of fluctuation, including coastal waves, currents, tides, and wind. These agents act by influencing energy intensity.

Therefore, the score for erosion frequency for this area is almost certain to happen. The severe impact of coastal erosion occurred extensively along most of the MU2 shoreline. The 
impacts of erosion differ depending on the risk of respondents/ recipients. Therefore, the score for magnitude of severity of the various risk recipients is based on the definition adapted from Thomsen et. al. (2012). Table 5 summarises the risk assessment analysis for erosion hazard in MU2 based on the risk matrix. The current condition in MU2 is shown in Figure 12.

Table 5. Risk analysis assessment on coastal erosion in MU2

\begin{tabular}{|c|c|c|c|c|}
\hline Hazard & $\begin{array}{c}\text { Risk } \\
\text { Respondent }\end{array}$ & Frequency & Severity & Risk \\
\hline \multirow{5}{*}{ Coastal Erosion } & Human & Almost certain to happen & Very low & Low \\
\hline & Social & Almost certain to happen & Very low & Low \\
\hline & Economy & Almost certain to happen & Very low & Low \\
\hline & Environment & Almost certain to happen & Moderate & High \\
\hline & Infrastructure & Almost certain to happen & Very low & Low \\
\hline
\end{tabular}

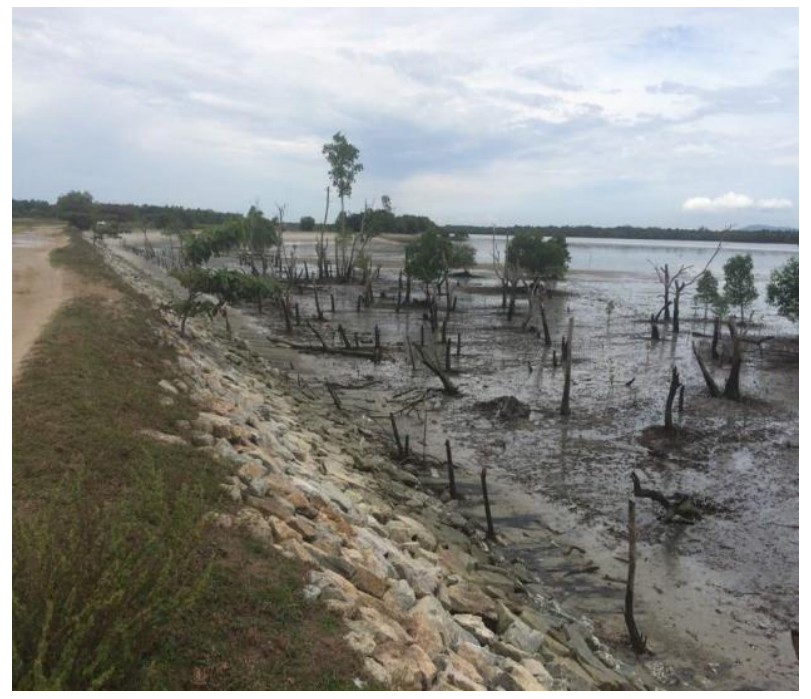

(a)

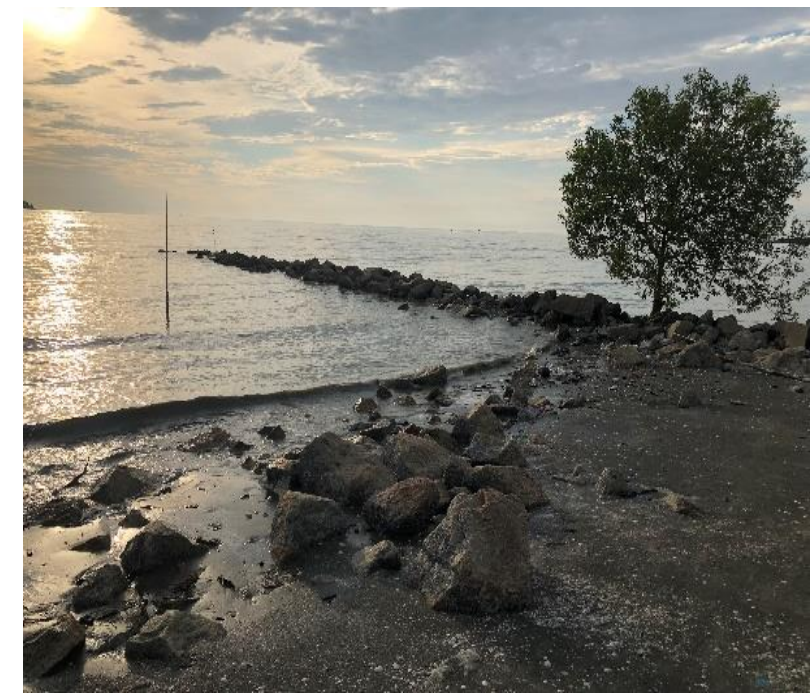

(b)

Figure 1. Current condition showing (a) mass rock installed as a protective measure for erosion at Pulau Indah; and (b) wave breaker at Pantai Jeram

\section{c. Coastal area of MU3}

The shoreline of MU3 showed the lowest rate of erosion compared to the rate for MU1 and MU2. The risk of erosion along the MU3 shoreline was assessed based on the frequency of erosion and the severity of the impact of coastal erosion. According to (Jaharudin et al., 2019; Rameli \& Jaafar, 2018; Selamat et al., 2017) the deposition at most of the beaches in Morib is due to land use activities that cause muddy sediments to be stranded at the mouth of the river due to the slow wave energy. The slow waves are not able to transfer the precipitated material far from the beach; in fact the moderate coastal currents may have transferred most of the terrestrial sediment to other areas along the coast. However, based on the observation made during the site visits, the erosion in the MU3 area is minimal. Therefore, the score for erosion frequency for this area is almost certain to happen. The severe impact of coastal erosion occurred along most of the MU3 shoreline. The 
impacts of erosion differ depending on the risk of respondents/ recipients. Therefore, the score for the magnitude of the severity of the various risk recipients is based on the definition adapted from the Thomsen et al., 2012. Table 5 summarises the risk assessment analysis for the erosion hazard at MU3 based on the risk matrix. Figure 13 shows the current condition in MU3.

Table 6. Risk analysis assessment on coastal erosion in MU1

\begin{tabular}{ccccc}
\hline Hazard & Risk & Frequency & Severity & Risk \\
\hline \multirow{4}{*}{ Respondent } & Human & Almost certain to happen & Very low & Low \\
& Social & Almost certain to happen & Very low & Low \\
& Economy & Almost certain to happen & Very low & Low \\
& Environment & Almost certain to happen & Moderate & High \\
& Infrastructure & Almost certain to happen & Minor & Moderate \\
\hline
\end{tabular}

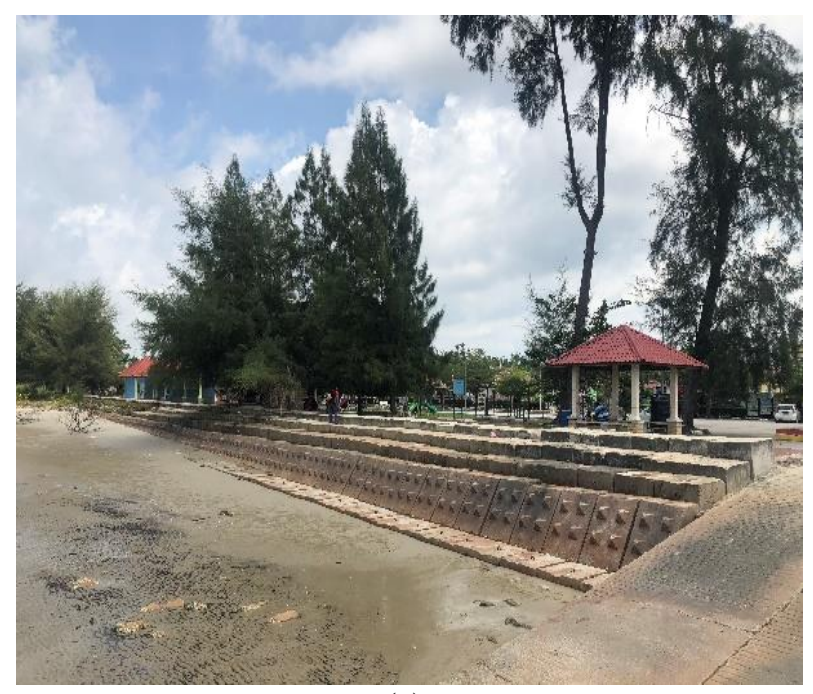

(a)

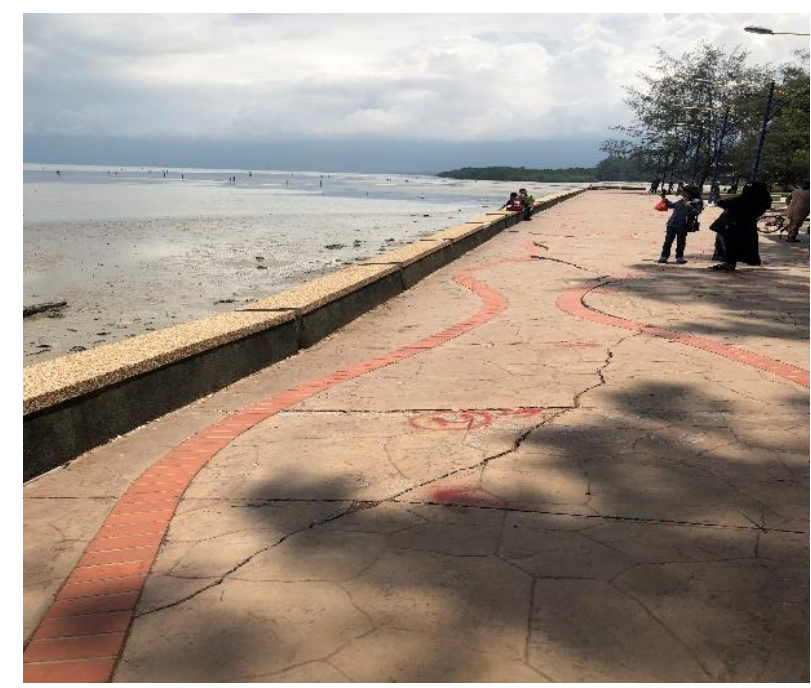

(b)

Figure 2. Current condition showing: (a) concrete block built as wave protection structure at Pantai Batu Laut; and (b) Sea walls showing signs of failure in Pantai Morib

\section{Conclusion}

The coastal area is an important natural resource and is a fragile area that has to be protected since it can easily change as a result of the impact of environmental activities. This study has shown that both erosion and deposition processes have caused changes in the position of shoreline along the Selangor coast. This study used a Geospatial technology that includes GIS and satellite images. Analysis of shoreline change assessment revealed that the study area has experienced a total area of erosion and accretion of 2,558 hectares and 2,583 hectares, respectively, between 1984 and 2013. The rate of erosion varies from 4.81 to $6.39 \mathrm{~m} /$ year while the rate of accretion ranges from 4.36 to $13.88 \mathrm{~m} /$ year. MU1 showed a higher erosion rate and has been identified as a critical erosion area. Hence, it can be concluded that a continuous rise in the sea level will bring about shoreline changes, including to the environmental and human activities in the coastal area stretching from Sabak Bernam to Kuala Langat. The results of the risk assessment analysis indicate 
that the risk level is low for human, social and economic components, and low to moderate for the infrastructure components. On the other hand the risk for coastal erosion hazards for the environment is high. The results obtained by this study provide valuable information for the formulation of a development plan for the Selangor coastal area.

\section{Acknowledgement}

The authors would like to express their gratitude to Universiti Kebangsaan Malaysia for providing the funding (DIP-2018-030 \& TRGS/1/2015/UKM/02/5/3) for this research. The authors wish to thank the Earth Observation Centre, Institute of Climate Change, UKM for providing the satellite data.

\section{References}

Asmawi, M. Z., \& Ibrahim, A. N. (2013). The perception of community on coastal erosion issue in Selangor, Malaysia. Journal of Clean Energy Technologies, 1(3), 164-168. https://doi.org/10.7763/JOCET.2013.V1.38

Bagheri, M., Zaiton Ibrahim, Z., Bin Mansor, S., Abd Manaf, L., Badarulzaman, N., \& Vaghefi, N. (2019). Shoreline change analysis and erosion prediction using historical data of Kuala Terengganu, Malaysia. Environmental Earth Sciences, 78(15). https://doi.org/10.1007/s12665-019-8459-x

Camara, M., Jamil, N. R., \& Abdullah, A. F. Bin. (2019). Impact of land uses on water quality in Malaysia: a review. Ecological Processes, 8(1). https://doi.org/10.1186/s13717-019-0164-X

Din Hashmi, S. G. M., \& Ahmad, S. R. (2018). GIS-Based analysis and modeling of coastline erosion and accretion along the coast of Sindh Pakistan. Journal of Coastal Zone Management, 21(1), 1-7. https://doi.org/10.4172/2473-3350.1000455

DOSH. (2008), Department of Safety and Health. Guidelines for Hazard Identification, Risk assessment and Risk Control (HIRARC). Malaysia.

Economic Planning Unit, (1985). National Coastal Erosion Study: Volume I, Jabatan Perdana Menteri Malaysia, Kuala Lumpur, Malaysia.

Ehsan, S., Ara Begum, R., Ghani Md Nor, N., \& Nizam Abdul Maulud, K. (2019). Current and potential impacts of sea level rise in the coastal areas of Malaysia. IOP Conference Series: Earth and Environmental Science, 228(1). https://doi.org/10.1088/1755-1315/228/1/012023

Granados, A.J. and Peterson, P.J. (1999), Hazardous waste indicators for national decision makers, Journal of Environmental Management, 55(4): 249-263.

Ghazali, N. H. M. (2006). Coastal erosion and reclamation in Malaysia. Aquatic Ecosystem Health and Management, 9(2), 237-247. https://doi.org/10.1080/14634980600721474

Hashim, A. M., \& Noor, N. D. M. (2013). Performance evaluation of innovative concrete armor unit for coastal protection structure. BEIAC 2013 - 2013 IEEE Business Engineering and Industrial Applications Colloquium, 673-678. https://doi.org/10.1109/BEIAC.2013. 6560215

Hashim, H., Suhatril, M., \& Hashim, R. (2017) Assessment of liquefaction hazard along shoreline areas of Peninsular Malaysia. Geomat Nat Hazards Risk, 8(2):1853-1868.

Hashim, R., Kamali, B., Tamin, N. M., \& Zakaria, R. (2010). An integrated approach to coastal 
rehabilitation: Mangrove restoration in Sungai Haji Dorani, Malaysia. Estuarine, Coastal and Shelf Science, 86(1), 118-124. https://doi.org/10.1016/j.ecss.2009.10.021

Hassan, M. I., \& Rahmat, N. H. (2016). The effect of coastline changes to local community's socialeconomic. International Archives of the Photogrammetry, Remote Sensing and Spatial Information Sciences - ISPRS Archives, 42(4W1), 25-36. https://doi.org/10.5194/isprsarchives-XLII-4-W1-25-2016

Initial National Communication, (2000). Malaysia's Initial National Communication, Ministry of Science, Technology and Environment, Malaysia, Volume 1, July.

Jaharudin, P., Kamarul, M. D., Abu, T. J., Haslina, M., \& Pravinassh, R. (2019). Impact of coastal erosion on local community: Lifestyle and identity. Disaster Advances, 12(2), 19-27.

JPBD, 2012. National Coastal Zone Physical Plan - Volume 1. Kuala Lumpur: Federal Department of Town and Country Planning Peninsular Malaysia.

Lee, S. C., Hashim, R., Motamedi, S., \& Song, K. Il. (2014). Utilization of geotextile tube for sandy and muddy coastal management: A review. Scientific World Journal, 2014. https://doi.org/10.1155/2014/494020

Mohammad, N. A., Sharifah, M. S. A., \& Juhari, M. A. (2007). Land use evaluation for Kuala Selangor, Malaysia using remote sensing and GIS technologies. Geografia-Malaysian Journal of Society and Space, 3(1), 1-19.

Mohd Azharn, M., Nizam Abdul Maulud, K., Norsakinah Selamat, S., Firoz Khan, M., Jaafar, O., Shafrina Wan Mohd Jaafar, W., Mastura Syed Abdullah, S., Ekhwan Toriman, M., Khairul Amri Kamarudin, M., Barzani Gasim, M., \& Juahir, H. (2018). Impact of Shoreline changes to the coastal development. International Journal of Engineering \& Technology, 7(3.14), 191. https://doi.org/10.14419/ijet.v7i3.14.16883

Mohd, F. A., Abdul Maulud, K. N., Karim, O. A., Begum, R. A., Awang, N. A., Ahmad, A., Wan Mohamed Azhary, W. A. H., Kamarudin, M. K. A., Jaafar, M., \& Wan Mohtar, W. H. M. (2019). Comprehensive coastal vulnerability assessment and adaptation for Cherating-Pekan coast, Pahang, Malaysia. Ocean and Coastal Management, 182(February). https://doi.org/10.1016/j.ocecoaman.2019.104948

Muslim, M. S. 2004. Shoreline mapping using satellite sensor imagery, University of Southampton, Faculty of Engineering, Science and Mathematics, School of Geography, Thesis for the degree of Doctor of Philosophy, March 2004, 212 pp

Nassar, K., Mahmod, W. E., Fath, H., Masria, A., Nadaoka, K., \& Negm, A. (2019). Shoreline change detection using DSAS technique: Case of North Sinai coast, Egypt. Marine Georesources and Geotechnology, 37(1), 81-95. https://doi.org/10.1080/1064119X.2018. 1448912

National Coastal Erosion Study. (2016). Jabatan Pengairan dan Saliran. Seminar Pemumian. Februari 2016.

National Hydraulic Research Institute of Malaysia, NAHRIM (2010). The study of Impact of Sea Level Rise in Pulau Langkawi. p3-1.

Nybakken. J. W. 1988. Biologi laut. suatu pendekatan ekologis. PT Gramedia. Jakarta.

Ong, J. E. (2000). Vulnerability of Malaysia to sea-level change. Centre for Marine and Coastal Studies, Universiti Sains Malaysia, Penang, Malaysia

Pantanahiran, W. (2019). Using remote sensing data for calculating the coastal erosion in southern Thailand. International Archives of the Photogrammetry, Remote Sensing and Spatial Information Sciences - ISPRS Archives, 42(3/W7), 51-56. https://doi.org/10.5194/ isprsarchives-XLII-3-W7-51-2019 
Rameli, N. L. F., \& Jaafar, M. (2018). Detecting coastline changes use GIS geospatial techniques in Island Carey- Morib Coast, Selangor, Malaysia. International Journal of the Malay World and Civilisation (Jurnal Antarabangsa Alam Dan Tamadun Melayu), 6(2), 17-22.

Razak, M. S. A., Suryadi, F. X., Jamaluddin, N., \& Nor, N. A. Z. M. (2018). Shoreline planform stability of embayed beaches along the Malaysian Peninsular coast. Journal of Coastal Research, 85, 631-635. https://doi.org/10.2112/si85-127.1

Salleh, A. M., \& Nadzir, N. (2019). Erosion caused by coastal structure. International Journal of Engineering and Advanced Technology, 8(6), 1996-2001. https://doi.org/10.35940/ijeat. F8696.088619

Selamat, S. N., Abdul Maulud, K. N., Jaafar, O., \& Ahmad, H. (2017). Extraction of shoreline changes in Selangor coastal area using GIS and remote sensing techniques. Journal of Physics: Conference Series, 852(1). https://doi.org/10.1088/1742-6596/852/1/012031

Stanley, O. D., \& Lewis, R. R. (2009). Strategies for mangrove rehabilitation in an eroded coastline of Selangor, Peninsular Malaysia. Journal of Coastal Development, 12(3), 142-154. http://www.ejournal.undip.ac.id/index.php/coastdev/article/viewFile/880/747

Thomsen, D. C., Smith, T. F., \& Keys, N. (2012). Adaptation or manipulation? Unpacking climate change response strategies. Ecology and Society, 17(3), 20.

United Nations Environment Programme (UNEP), 2008, Disaster risk management for coastal tourism destinations responding to climate change: A practical guide for decision makers. United Nation.

Yanalagaran, R., \& Ramli, N. I. (2018). Assessment of coastal erosion related to wind characteristics in peninsular Malaysia. Journal of Engineering Science and Technology, 13(11), 3677-3690.

Zhang, Y., \& Hou, X. (2020). Characteristics of coastline changes on southeast Asia Islands from 2000 to 2015. Remote Sensing, 12(3). https://doi.org/10.3390/rs12030519 